\title{
Continuous Clarification of Barberry Juice with Pectinase Immobilised by Oxidised Polysaccharides
}

\section{Seyed Saeid Hosseiniఠ, Faramarz Khodaiyan*๑, Seyed Mohammad \\ Mousaviø and Seyedeh Zahra Azimi®}

Bioprocessing and Biodetection Laboratory, Department of Food Science and Engineering, University of Tehran, 31587-77871 Karaj, Iran

Received: 10 September 2020 Accepted: 21 March 2021

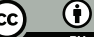

*Corresponding author:

Phone: +982632248804

Fax: +982632248804

E-mail:khodaiyan@ut.ac.ir

\section{SUMMARY}

Research background. Barberry juice is a rich source of bioactive compounds and shows different health properties such as antioxidant and anticancer activities. Clarification, as the removal process of suspended material, is an important step in the production of fruit juice due to its significant effect on the appearance, flavour and commercialisation of juice. Pectinase is the most important enzyme applied in juice clarification that breaks down the pectin polymer structure and reduces the undesirable turbidity. Pectinase immobilisation is a way to overcome free enzyme drawbacks such as instability, high cost, the difficulty of recovery and recyclability. Also, continuous clarification process which is highly preferred in fruit juice industry is not possible without enzyme immobilisation.

Experimental approach. Pectinase enzymes were immobilised on the functionalised glass beads (glass bead with (3-aminopropyl)triethoxysilane) by glutaraldehyde and polyaldehyde derivatives of pullulan and kefiran, and the barberry juice was clarified in the batch and continuous processes in a packed bed reactor (PBR). Also, the effect of clarification on the physicochemical and antioxidant properties of the barberry juice samples was evaluated.

Results and conclusions. The optimum conditions for clarification in the PBR were: flow rate $0.5 \mathrm{~mL} / \mathrm{min}$, temperature $50^{\circ} \mathrm{C}$ and treatment time $63 \mathrm{~min}$. Clarification led to a decrease in turbidity, pH, total soluble solid content, viscosity, total phenolic content and antioxidant activity of the juice samples. Also, this process increased the clarity, acidity, reducing sugar concentration and the lightness parameter of the barberry juice. The greatest effect of clarification on the studied properties of barberry juice was related to the pectinase immobilised by the polyaldehyde of kefiran in the continuous process and both new cross-linkers (polyaldehyde derivatives of pullulan and kefiran) immobilised the enzyme better than the common cross-linker (glutaraldehyde).

Novelty and scientific contribution. For the first time, barberry juice was clarified with pectinase immobilised by polyaldehyde derivatives of pullulan and kefiran and the obtained results showed that the pectinase immobilisation by these new cross-linkers was much more efficient than by the glutaraldehyde as a common cross-linker. These findings can be of use for an industrialised production of fruit juices.

Key words: barberry juice, pectinase, polyaldehyde derivatives of polysaccharides, immobilisation, packed bed reactor

\section{INTRODUCTION}

Barberry (Berberis vulgaris L.) fruit, as the largest genus of Berberidaceae family, is a rich source of bioactive compounds such as carotenoids, flavonoids, anthocyanins and polyphenols, and therefore shows different health properties, e.g. antioxidant and anticancer activities (1). Besides, in traditional medicine, this fruit and especially its juice have a wide application in the treatment of colitis, chronic inflammation, high blood pressure, and nervous, liver and heart problems (2). Considering these health benefits, it is highly recommended to consume barberry juice as one of the most important nutraceutical beverages. An overview of the production process of barberry juice reveals that its main 
stages include separation of fruit and washing, raw juice production, clarification, heat treatment and packaging. Among these steps, clarification, which is theoretically defined as the removal of suspended material that causes turbidity and sediment in the product, is particularly important due to its significant effect on the appearance, flavour, customer attention and commercialisation of juice. The main cause of turbidity and sediment is a hydrocolloid named pectin, a polymer of a-1,4-galacturonic acid that makes up approx. $30 \%$ of the primary cell wall of plants and enters the product during the juicing process $(3,4)$; therefore, it is necessary to remove it. In conventional industrial production, this process is done with the help of gelatin, bentonite and different types of membranes (5). However, with the advancement of science and the increasing demand for more selective and clean processes in recent years, the enzymes have gained a special place in this process because they have high efficiency, selectivity, low toxicity and also operate under mild reaction conditions (6-8).

Pectinase is the most important enzyme employed in juice clarification that breaks down the pectin polymer structure and reduces the undesirable turbidity, cloudiness and sediment (9). Although the use of free pectinase in the juice production can be considered as a potential method, it has some drawbacks such as instability, high cost and the difficulty of recovery and recyclability, which limit its industrial application (10). The way to solve these problems is carrier-bound and carrier-free immobilisation. Carrier-bound immobilisation refers to the process of connecting an enzyme on a suitable support surface by different methods including adsorption, entrapment and covalent binding (11-13), while carrier-free immobilisation is a direct cross-linking of different enzyme preparations $(14,15)$. Abdel Wahab et al. (16) stated that the covalent immobilisation of pectinase on the alginate-agar gel by glutaraldehyde increased significantly the stability of the enzymes. Hassan et al. (17) immobilised pectinase and xylanase enzymes on the alginate beads and reported that the used method was highly efficient in the clarification of apple juice. Benucci et al. (18) reported that the immobilisation of pectinase and protease enzymes on the chitosan beads by polydialdehyde starch can be considered as an efficient method for clarifying pomegranate juice. There are two key parts of the support and immobilisation method in this definition that determine the capabilities and performance of the system. Regarding support, it would be wise to choose glass beads because the enzymatic system undergoes stress during juice clarification, so it is important to choose a resistant support. In addition to excellent resistance to the stress conditions, the glass beads have received considerable attention as an insoluble support with high capacity to bind enzymes (19). Considering the immobilisation method, it seems that covalent binding, as one of the strongest chemical bonds used to immobilise enzymes, is the best method in the industrial applications due to lower probability of the release of enzymes from the support and thus higher stability and reusability (20-22). For the binding of the enzyme to the support, the existence of a cross-linker is essential. To the best of our knowledge, in all studies where glass bead is used as an enzyme carrier, glutaraldehyde is applied as a cross-linker $(19,23)$. It is a toxic material in all doses and therefore its use is associated with concerns and challenges. In previous studies, we applied polyaldehyde derivatives of kefiran and pullulan (produced by partial oxidation with sodium periodate) as new cross-linkers to immobilise pectinase on the functionalised glass beads (glass beads with (3-aminopropyl)triethoxysilane) and the obtained results showed that the used polyaldehyde polysaccharides were comparable with glutaraldehyde and also could bind higher amount of enzymes to the support (24).

One of the most important advantages of immobilised enzymes is the capability to perform a continuous enzymatic process after immobilisation. The first step in performing such continuous enzymatic process is the preparation or manufacture of a bioreactor. Packed bed reactor (PBR) is a simple and inexpensive reactor with a double-walled cylinder packed with support-immobilised enzymes (Fig. 1), which

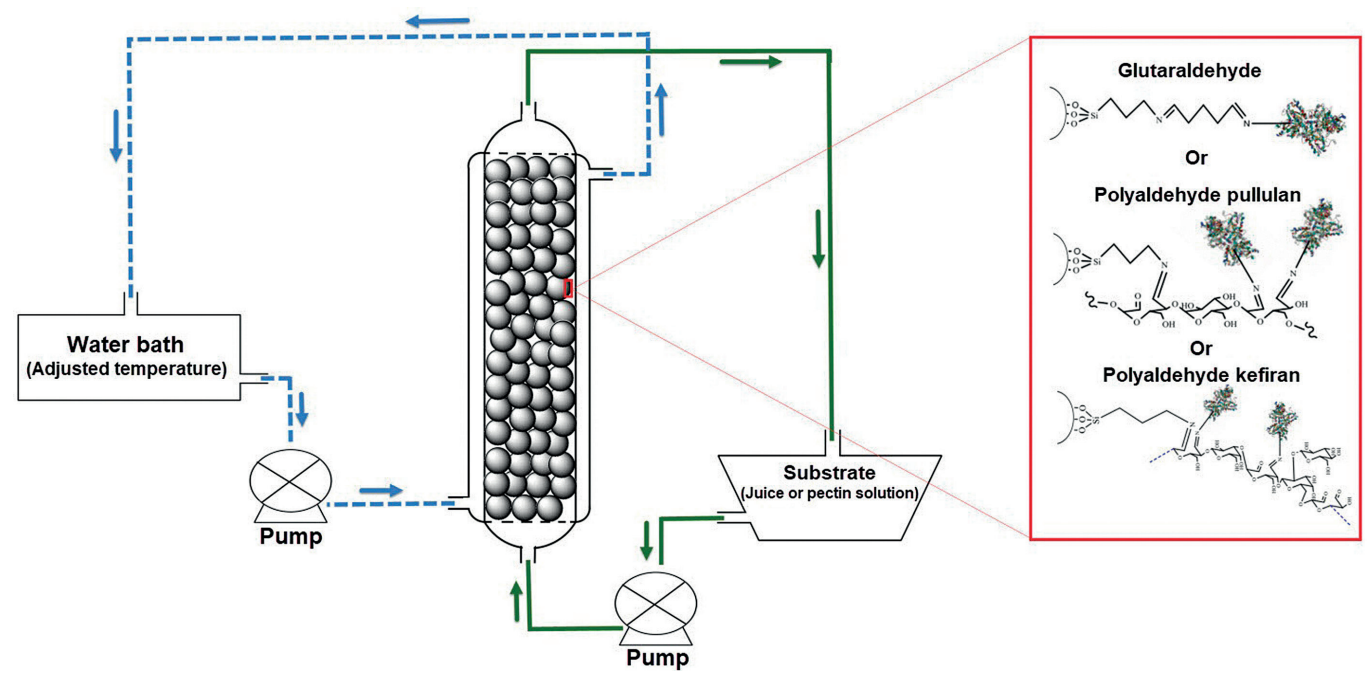

Fig. 1. Schematic illustration of the configuration of the continuous packed bed reactor used in the study 
has so far been used successfully in many studies $(11,25)$. For example, Dal Magro et al. (26) reported that pectinase immobilised on chitosan particles and used in PBR seems to be a good alternative for large scale application for juice clarification. In another study, Benucci et al. (27), who used PBR for white wine protein stabilisation by the immobilised cysteine proteases, reported that the enzymatic treatment in PBR can be used as an alternative to bentonite fining.

As mentioned above, the feasibility of using polyaldehyde derivatives of polysaccharides (kefiran and pullulan) as new cross-linkers for the immobilisation of pectinase on the glass beads was investigated in previous studies $(24,28)$. However, the performance of this immobilisation system under real conditions remains unclear. Without checking the obtained results of juice clarification, the efficiency of this system cannot be judged. Therefore, keeping in mind broad applications of immobilised enzymes in the juice industry, in this study, a continuous clarification of barberry juice using PBR charged with polyaldehyde polysaccharide-immobilised pectinase on glass beads was investigated. Also, the physicochemical and antioxidant properties of the barberry juice samples clarified by polyaldehyde polysaccharide-immobilised pectinase were compared with the samples clarified by free and glutaraldehyde-immobilised enzymes.

\section{MATERIALS AND METHODS}

\section{Materials}

Pectinase enzyme (Pectinex ${ }^{\circledR}$ Ultra Color) with a protein concentration of $80 \mathrm{mg} / \mathrm{mL}$ was obtained from Novozymes (Bagsvaerd, Denmark). Also, the preliminary experiments showed that the specific activity of the applied pectinase was $(2.93 \pm 0.13) \mathrm{U} / \mathrm{mg}$ at the temperature $50{ }^{\circ} \mathrm{C}$ and $\mathrm{pH}=5.0$ (optimum conditions for free pectinase activity).

Apple pectin with degree of esterification of $72-76 \%$ was bought from Herbstreith \& Fox KG (Neuenbuerg, Germany). Kefiran and pullulan exopolysaccharides were supplied by Microbiology Laboratory, Department of Food Science and Engineering, University of Tehran (Karaj, Iran) and Herbstreith \& Fox KG, respectively. Glass beads with $6 \mathrm{~mm}$ diameter were provided by Iran Beads Co. (Esfahan, Iran). The (3-aminopropyl)triethoxysilane (3-APTES), 3,5-dinitrosalicylic acid (DNS), glutaraldehyde, hydroxylamine hydrochloride, sodium periodate and $\mathrm{D}-(+)$-galacturonic acid monohydrate were purchased from Sigma Chemical Co., Merck (St. Louis, MO, USA). All other chemicals and reagents were of analytical grade.

\section{Preparation of polyaldehyde polysaccharides}

The partial oxidation reaction with sodium periodate was applied to produce the polyaldehyde derivatives of kefiran and pullulan (29). To produce each polyaldehyde polysaccharide, $5 \mathrm{~g}$ sodium periodate powder were dissolved in $100 \mathrm{~mL}$ distilled water and the obtained solution was slowly added to $250 \mathrm{~mL}$ polysaccharide aqueous solution $(4 \% \mathrm{~m} / \mathrm{V})$ under stirring. After adjusting $\mathrm{pH}$ to 5 by adding $1 \mathrm{M}$ sulfuric acid solution, the reaction was continued in the dark for $3 \mathrm{~h}$ at
$(40 \pm 2)^{\circ} \mathrm{C}$. To precipitate polysaccharides, $96 \%$ ethanol in volume ratio $V($ ethanol $) / V$ (polysaccharide solution) $=2: 1$ was added and the resulting mixture was stored in a refrigerator $\left(7^{\circ} \mathrm{C}\right.$ for 3 days). Afterwards, the oxidised polysaccharides were separated by centrifugation at $10000 \times g$ for $20 \mathrm{~min}$, washed three times with distilled water and subsequently freeze-dried for a day. The aldehyde mass fraction in polyaldehyde derivatives of kefiran and pullulan obtained by the method of Kholiya et al. (30) using hydroxylamine hydrochloride was $(23.6 \pm 0.9)$ and $(19.9 \pm 1.3) \%$, respectively.

\section{Immobilisation of pectinase on glass beads}

In this study, the cross-linkers of glutaraldehyde, polyaldehyde derivatives of kefiran and pullulan were applied to immobilise pectinase on glass beads according to the method of Gomez et al. (19). Glass beads ( $23 \mathrm{~cm}^{3}$, approx. 110 beads) were washed with $5 \% \mathrm{HNO}_{3}$ at approx. $85^{\circ} \mathrm{C}$ for $120 \mathrm{~min}$ and then dried at $110^{\circ} \mathrm{C}$ for $24 \mathrm{~h}$. In the next step, the functionalised glass beads were prepared by mixing them with $10 \% \mathrm{~V} / \mathrm{V}$ (3-aminopropyl)triethoxysilane (3-APTES) solution for $3 \mathrm{~h}$ at $60{ }^{\circ} \mathrm{C}$ and a constant $\mathrm{pH}=4$ (adjusted with $6.0 \mathrm{M} \mathrm{HCl}$ ). After washing with distilled water and drying at $80^{\circ} \mathrm{C}$ for $24 \mathrm{~h}$, the glass beads were slowly stirred in glutaraldehyde solution $(2.5 \% \mathrm{~V} / \mathrm{V})$ or polyaldehyde derivatives of kefiran $(2.5 \% \mathrm{~m} / \mathrm{V})$ or pullulan $(2.5 \% \mathrm{~m} / \mathrm{V})$ for $2.5 \mathrm{~h}$ at room temperature (approx. $23^{\circ} \mathrm{C}$ ). The glass beads were then immersed in pectinase solution diluted with sodium acetate buffer $(\mathrm{pH}=4$ and ratio 1:4 (5 mL enzyme solution with $80 \mathrm{mg} / \mathrm{mL}$ protein and $20 \mathrm{~mL}$ buffer)) for $5 \mathrm{~h}$ at room temperature (approx. $23^{\circ} \mathrm{C}$ ), then washed with the same buffer and stored at $4{ }^{\circ} \mathrm{C}$.

The protein mass of the glass beads after pectinase immobilisation by glutaraldehyde, polyaldehyde kefiran and polyaldehyde pullulan, respectively, was (4.5 \pm 0.7$)$, (57.8 \pm 1.1$)$ and (20.1 \pm 1.0$) \mathrm{mg}$ in $23 \mathrm{~cm}^{3}$ glass beads according to Lowry method (31) calculated as follows:

$$
m(\text { protein })=m_{\mathrm{I}}-\left(m_{\mathrm{R}}+m_{\mathrm{W}}\right)
$$

where $m_{1}, m_{R}$ and $m_{W}$ are the protein content of the initial, remaining and washing solutions, respectively.

Also, the specific activity of pectinase immobilised by glutaraldehyde, polyaldehyde derivatives of kefiran and pullulan, respectively, was $2.6 \pm 0.1$ (activity recovery of $87.4 \%$ ), $1.9 \pm 0.2$ (activity recovery of $63.8 \%$ ) and $2.2 \pm 0.2$ (activity recovery of $75.4 \%) \mathrm{U} / \mathrm{mg}$ protein according to the described method in a previous study (DNS method) (24). One unit was defined as the enzyme content required to form $1 \mu \mathrm{mol} / \mathrm{min}$ galacturonic acid under the experimental conditions.

\section{Kinetic parameters}

The Michaelis-Menten constant $\left(K_{\mathrm{m}}\right)$ and the maximum reaction rate $\left(v_{\max }\right)$ were determined as follows:

$$
\frac{1}{v}=\frac{K_{\mathrm{m}}}{v_{\max }} \cdot \frac{1}{[\mathrm{~S}]}+\frac{1}{v_{\max }}
$$

where $[S]$ is pectin concentration $(2-20 \mathrm{mg} / \mathrm{mL})$. 
It should also be noted that the enzymatic reaction conditions were based on the DNS method (24). For this purpose, the enzyme immobilised on $20 \mathrm{~cm}^{3}$ glass beads was added to $10 \mathrm{~mL}$ of $1 \%(\mathrm{~m} / \mathrm{V})$ pectin solution prepared with $0.1 \mathrm{M} \mathrm{so-}$ dium acetate buffer $(\mathrm{pH}=5.5)$ and hydrolysed for $15 \mathrm{~min}$ at $50^{\circ} \mathrm{C}$. After that, $1 \mathrm{~mL}$ of the reaction medium was poured in a test tube and $1 \mathrm{~mL}$ of DNS reagent was added to it. The resulting solution was immediately placed in bain-marie $\left(100^{\circ} \mathrm{C}\right.$, $5 \mathrm{~min}$ ) and then cooled in an ice-water bath. Afterwards, $3 \mathrm{~mL}$ distilled water were added to the test tube and its absorbance was determined at $540 \mathrm{~nm}$. D-galacturonic acid (10-1000 $\mu \mathrm{g} /$ $\mathrm{mL}$ ) was used to draw a standard curve.

\section{Preparation of barberry juice}

The barberry fruits were obtained from a local store in Karaj, Alborz, Iran. The fruits were first separated from the branches and then thoroughly washed. In the next step, barberry juice was made in a household juicer (SJ 3000 W; BRAUN, Shanghai, PR China). The obtained juice was filtered through a Whatman No. 1 paper to separate the insoluble materials and then stored in a refrigerator until next use.

\section{Packed bed reactor system}

To carry out a continuous process, a jacketed glass reactor with an inner diameter of $14 \mathrm{~mm}$ and a length of $150 \mathrm{~mm}$ was used. This bioreactor was well packed with $23 \mathrm{~cm}^{3}$ of pectinase-immobilised glass beads (approx. 110 beads). The packed bed reactor (PBR) was fed from the bottom with $1 \%$ $(\mathrm{m} / \mathrm{V})$ buffered pectin solution $(\mathrm{pH}=3)$ or barberry juice $(\mathrm{pH}=3.01)$, while the temperature was adjusted with the water flow in the outer layer (Fig. 1). The total volume of the PBR was $23.08 \mathrm{~cm}^{3}$, while the actual volume of $23 \mathrm{~cm}^{3}$ of glass beads ( 110 beads) was $12.43 \mathrm{~cm}^{3}$ and thereby the void volume was $10.65 \mathrm{~cm}^{3}$ according to the formula below:

$$
V_{\mathrm{V}}=V_{\mathrm{T}}-V_{\mathrm{A}}
$$

where $V_{V}$ and $V_{T}$ are the void and total volume of the PBR and $V_{A}$ is the actual volume of $23 \mathrm{~cm}^{3}$ of glass beads.

\section{Effect of flow rate, temperature and treatment time on PBR performance}

The effect of flow rate, temperature and treatment time on the activity of the immobilised pectinase under a continuous process in the PBR was evaluated using one factor at a time design. For flow rate, this factor was variable $(0.1-10 \mathrm{~mL} /$ $\mathrm{min})$, while the temperature and $\mathrm{pH}$ of the $1 \%(\mathrm{~m} / \mathrm{V})$ pectin solution were constant at $50{ }^{\circ} \mathrm{C}$ and $3.0(\mathrm{pH}$ of the tested juice), respectively. For each flow rate, the residence time (min) can also be calculated as follows:

$$
t(\text { residence })=\frac{V_{V}}{Q}
$$

where $V_{v}$ is the void volume of the reactor $(\mathrm{mL})$ and $Q$ is the flow rate $(\mathrm{mL} / \mathrm{min})$.
To determine the best temperature, this factor was varied from 30 to $90{ }^{\circ} \mathrm{C}$, and the flow rate and $\mathrm{pH}$ of the $1 \%(\mathrm{~m} / \mathrm{V})$ pectin solution were considered constant at $0.5 \mathrm{~mL} / \mathrm{min}$ and 3.0, respectively. To determine the flow rate and temperature, the substrate was pectin solution $(1 \% \mathrm{~m} / \mathrm{V})$ and the response was reducing sugar concentration $(\mathrm{mg} / \mathrm{mL})$ determined by the DNS method as stated earlier (32).

To determine the best treatment time, this factor was varied from 0 to $105 \mathrm{~min}$, while the flow rate $(0.5 \mathrm{~mL} / \mathrm{min})$ and temperature $\left(50{ }^{\circ} \mathrm{C}\right)$ were fixed. In this experiment the barberry juice was the substrate and the turbidity was the response. For this purpose, after the clarification at different treatment times, the turbidity of the obtained juice was determined by a portable turbidimeter ( 350 IR; WTW, Weilheim, Germany) and the results were reported as nephelometric turbidity unit (NTU).

\section{Volumetric productivity of free and immobilised pectinases in batch and continuous systems}

Under the batch conditions, the volumetric productivity of free pectinase and the enzymes immobilised by different cross linkers was determined by adding $56 \mu \mathrm{L}$ free enzyme or $23 \mathrm{~cm}^{3}$ glass bead-immobilised enzymes to $10.65 \mathrm{~mL}$ pectin solution and performing the hydrolysis reaction under optimal conditions as mentioned earlier. The volumetric productivity was reported based on $\mathrm{mg}$ of the produced reducing sugar per $\mathrm{mL}$ of medium per $\mathrm{min}(\mathrm{mg} /(\mathrm{mL} \cdot \mathrm{min})$ ). In the continuous process, this parameter was also calculated as follows (33):

$$
P_{\mathrm{V}}=\gamma \cdot \frac{1}{t(\text { residence })}
$$

where $\gamma$ is the concentration of the produced reducing sugar (in $\mathrm{g} / \mathrm{mL}$ ).

\section{Enzymatic clarification of barberry juice}

For this purpose, the use of free and immobilised pectinase was investigated under batch and continuous conditions. In the batch process, $56 \mu \mathrm{L}$ free enzyme or $23 \mathrm{~cm}^{3}$ enzyme-immobilised glass beads were immersed into $10.65 \mathrm{~mL}$ barberry juice and clarification was done at $50^{\circ} \mathrm{C}$ for $63 \mathrm{~min}$. In the case of the continuous operation, the fruit juice was pumped into the PBR with a flow rate of $0.5 \mathrm{~mL} / \mathrm{min}$ under the same conditions $\left(50^{\circ} \mathrm{C}, 63 \mathrm{~min}\right)$. Generally, in the current study, seven clarification treatments were considered and the obtained results were compared with untreated juice. The treatments were: raw barberry juice, barberry juice clarified with free pectinase, barberry juice clarified with pectinase immobilised on the glass beads by glutaraldehyde in the batch operation, barberry juice clarified with pectinase immobilised on the glass beads by glutaraldehyde in the continuous operation, barberry juice clarified with pectinase immobilised on the glass beads by polyaldehyde derivative of pullulan in the batch operation, barberry juice clarified with pectinase immobilised on the glass beads by polyaldehyde 
derivative of pullulan in the continuous operation, barberry juice clarified with pectinase immobilised on the glass beads by polyaldehyde derivative of kefiran in the batch operation, and barberry juice clarified with pectinase immobilised on the glass beads by polyaldehyde derivative of kefiran in the continuous operation.

\section{Physicochemical characterisation of barberry juice}

In this section, the physicochemical properties of raw and treated barberry juice were determined. The turbidity of the juice samples was determined with a portable turbidimeter (350 IR; WTW) and expressed in NTU. The clarity of juice samples diluted with distilled water (fivefold) was obtained by recording the absorbance at $660 \mathrm{~nm}$ using a spectrophotometer (CE 2502; CECIL, Cambridge, UK) and calculating the transmittance $T$ (in \%) according to the equation below:

$$
T=10^{(2-A)}
$$

The $\mathrm{pH}$ was measured using a $\mathrm{pH}$ meter (GLP 22; Crison Instruments, Barcelona, Spain). Total titratable acidity (TTA) was determined by the titration with $0.1 \mathrm{M} \mathrm{NaOH}$ in the presence of phenolphthalein as indicator and was expressed in $\mathrm{g}$ malic acid per $100 \mathrm{~mL}$ juice.

Total soluble solid content (TSS) was determined with a refractometer (Bellingham-Stanley ${ }^{\mathrm{TM}}$ Abbe, London, UK) at room temperature and reported in ${ }^{\circ}$ Brix. The reducing sugar mass concentration $(\mathrm{mg} / \mathrm{mL})$ of the samples was measured using the DNS method as mentioned earlier.

The viscosity of the barberry juice samples was determined with a programmable viscometer (DV3TLVTJO; Ametek Brookfield, Middleborough, MA, USA) at a shear rate of $50 \mathrm{rpm}$ and $23^{\circ} \mathrm{C}$.

The presence of pectin was determined by adding ethanol to juice samples at volume ratio 2:1 and then storing the obtained mixtures at $4{ }^{\circ} \mathrm{C}$ for $24 \mathrm{~h}$. In this test, the lack of supernatant formation shows the complete elimination of pectin.

The colour parameters of different samples were obtained by a colour reader (CR-400; CHROMA METER, Tokyo, Japan).

Total phenolic content (TPC) was determined using the Folin-Ciocalteu method $(34,35)$. A volume of $100 \mu \mathrm{L}$ of barberry juice was added to $500 \mu \mathrm{L}$ of $10 \%$ Folin-Ciocalteu reagent solution and then $400 \mu \mathrm{L}$ of $10 \%(\mathrm{~m} / \mathrm{V})$ sodium carbonate solution were poured into it. After $1 \mathrm{~h}$ in darkness, the absorbance was read at $517 \mathrm{~nm}$ using a spectrophotometer (CE 2502; CECIL) and the TPC was calculated by the comparison of the determined absorbance with the standard curve obtained for gallic acid $(10-100 \mu \mathrm{g} / \mathrm{mL})$. The TPC was reported as mg gallic acid equivalent per $\mathrm{mL}$ barberry juice.

\section{Determination of antioxidant activity of barberry juice}

Antioxidant activity was evaluated by the DPPH radical scavenging activity of barberry juice $(34,36)$. For this purpose, $100 \mu \mathrm{L}$ barberry juice diluted with distilled water (200-fold) were added to $1.9 \mathrm{~mL}$ of DPPH ethanolic solution $(0.1 \mathrm{mM})$ and the obtained mixture was vortexed. The absorbance of samples was recorded at $517 \mathrm{~nm}$ after storing in darkness for 30 min and the DPPH radical scavenging activity (DPPH-RSA) was calculated as follows:

$$
\text { DPPH-RSA }=\frac{A_{\text {control }}-A_{\text {sample }}}{A_{\text {control }}} \cdot 100
$$

ABTS radical scavenging activity (ABTS-RSA) was determined in a similar way to DPPH-RSA. It should only be noted that to produce ABTS radical solution, 7.4 mM ABTS solution was mixed with $2.6 \mathrm{mM}$ potassium persulfate and after storing in darkness for $18 \mathrm{~h}$, its absorbance was adjusted to $0.70 \pm 0.02$ at $734 \mathrm{~nm}$ by adding distilled water (34). Also, in this experiment, the absorbance of the obtained samples was measured at $734 \mathrm{~nm}$.

\section{Statistical analysis}

All the experiments were performed in triplicate and their results were expressed as mean value \pm S.D. The obtained data were subjected to one-way analysis of variance (ANOVA) using SPSS software v. 20 (37). It must also be stated that a significance level of $a=0.05$ was applied.

\section{RESULTS AND DISCUSSION}

\section{Kinetic parameters of immobilised pectinases}

The kinetic parameters of the immobilised pectinases including Michaelis-Menten constant $\left(K_{\mathrm{m}}\right)$ and the maximum reaction rate $\left(v_{\max }\right)$ were calculated at temperature of $50{ }^{\circ} \mathrm{C}$ and $\mathrm{pH}=5.5$. The obtained results showed $K_{\mathrm{m}}$ for pectinase immobilised by glutaraldehyde, polyaldehyde derivatives of pullulan and kefiran were (10.1 \pm 0.4$),(11.2 \pm 0.2)$ and (11.6 \pm 0.3$)$ $\mathrm{mg} / \mathrm{mL}$, respectively. Also, $v_{\max }$ value, on protein basis, for pectinase immobilised by the mentioned cross-linkers was $(2.9 \pm 0.3),(2.2 \pm 0.2)$ and $(2.2 \pm 0.1) \mu \mathrm{mol} /(\mathrm{min} \cdot \mathrm{mg})$, respectively. The $K_{\mathrm{m}}$ and $v_{\max }$ of the pectinase immobilised by polyaldehyde derivatives of pullulan and kefiran were higher and lower than of the pectinase immobilised by glutaraldehyde, which can be due to the diffusion limitation effects created by the polymeric network and three-dimensional structure of the polyaldehyde derivatives of pullulan and kefiran (28).

\section{Effect of flow rate, temperature and treatment time on the activity of immobilised pectinase in PBR}

To determine the effect of flow rate on the activity of immobilised pectinase in the PBR, the reducing sugar production by pectinase immobilised using different cross-linkers was studied (substrate was $1 \%(\mathrm{~m} / \mathrm{V})$ buffered pectin solution at $\mathrm{pH}=3$ and constant temperature at $50{ }^{\circ} \mathrm{C}$ ). Fig. $2 \mathrm{a}$ shows that the reducing sugar production in a bioreactor packed with pectinase immobilised by polyaldehyde derivative of kefiran was higher than that of the enzymes immobilised by two other cross-linkers (glutaraldehyde and polyaldehyde derivative of pullulan) at all flow rates. This result is probably due to higher protein immobilisation on $23 \mathrm{~cm}^{3}$ 
glass beads by polyaldehyde derivative of kefiran $((57.8 \pm 1.1) \mathrm{mg})$ than polyaldehyde derivative of pullulan $((20.1 \pm 1.0) \mathrm{mg})$ and glutaraldehyde $((4.5 \pm 0.7) \mathrm{mg})$. Also, the reducing sugar production decreased when the flow rate was increased from 0.1 (residence time of $106.5 \mathrm{~min}$ ) to 10 (residence time of $1.065 \mathrm{~min}$ ) $\mathrm{mL} / \mathrm{min}$, which can be related to shorter contact between the immobilised enzymes and substrate when the flow rate is increased (38). However, there is no significant difference between the reducing sugar productions at flow rates from 0.1 to $0.5 \mathrm{~mL} / \mathrm{min}$. Therefore, to save time and cost, other experiments in this study were performed at a flow rate of $0.5 \mathrm{~mL} /$ min (residence time of $21 \mathrm{~min}$ ).

Fig. $2 \mathrm{~b}$ shows the effect of treatment temperature (30$90^{\circ} \mathrm{C}$ ) on the reducing sugar production by pectinase immobilised using different cross-linkers, while other parameters remained constant ( $\mathrm{pH}=3$ and flow rate $0.5 \mathrm{~mL} / \mathrm{min}$ ). In this experiment, similar to the flow rate, the reducing sugar production in the bioreactor packed with pectinase immobilised by polyaldehyde derivative of kefiran was higher than that of the enzyme immobilised by glutaraldehyde and/or polyaldehyde derivative of pullulan at all temperatures. The obtained results indicated that the maximum reducing sugar production was achieved at $50^{\circ} \mathrm{C}$ with pectinase immobilised by all three cross-linkers. These results were probably attributed to the optimum temperature for the activity of immobilised pectinase by the mentioned cross-linkers, as shown in a previous study (24). However, it seems that the type of immobilisation and the used cross-linker are the key factors in this analysis. For instance, Dal Magro et al. (39) reported that the optimum temperature for the activity of pectinase immobilised on the glutaraldehyde-activated magnetite was $60^{\circ} \mathrm{C}$, while de Oliveira et al. (11) stated that this parameter for pectinase immobilised on the alginate beads was $50^{\circ} \mathrm{C}$.

To evaluate the effect of treatment time on the fruit juice clarification in the bioreactor packed with pectinase immobilised on glass beads, the turbidity of the barberry juice was measured at different treatment times (0-105 min), while the flow rate and temperature were constant, $0.5 \mathrm{~mL} / \mathrm{min}$ and $50{ }^{\circ} \mathrm{C}$, respectively. As observable in Fig. $2 \mathrm{c}$, the turbidity of the samples reached a minimum after $63 \mathrm{~min}$ and a further increase in time had no significant effect on this factor. However, the slope of the turbidity reduction in the bioreactor packed with pectinase immobilised by polyaldehyde derivative of kefiran was greater than the other two used cross-linkers, which was possibly due to the higher amount of the enzyme immobilised by this cross-linker. Therefore, all tests on the treated barberry juice were performed after clarification at a flow rate of $0.5 \mathrm{~mL} / \mathrm{min}$, temperature of $50{ }^{\circ} \mathrm{C}$ and treatment time of $63 \mathrm{~min}$ for continuous and the same temperature and treatment time for the batch operation.

\section{Results of volumetric productivity of free and immobilised pectinase in batch and continuous operations}

In this experiment, the volumetric productivity of free pectinase and pectinase immobilised by different cross-linkers in batch and continuous operations was determined and
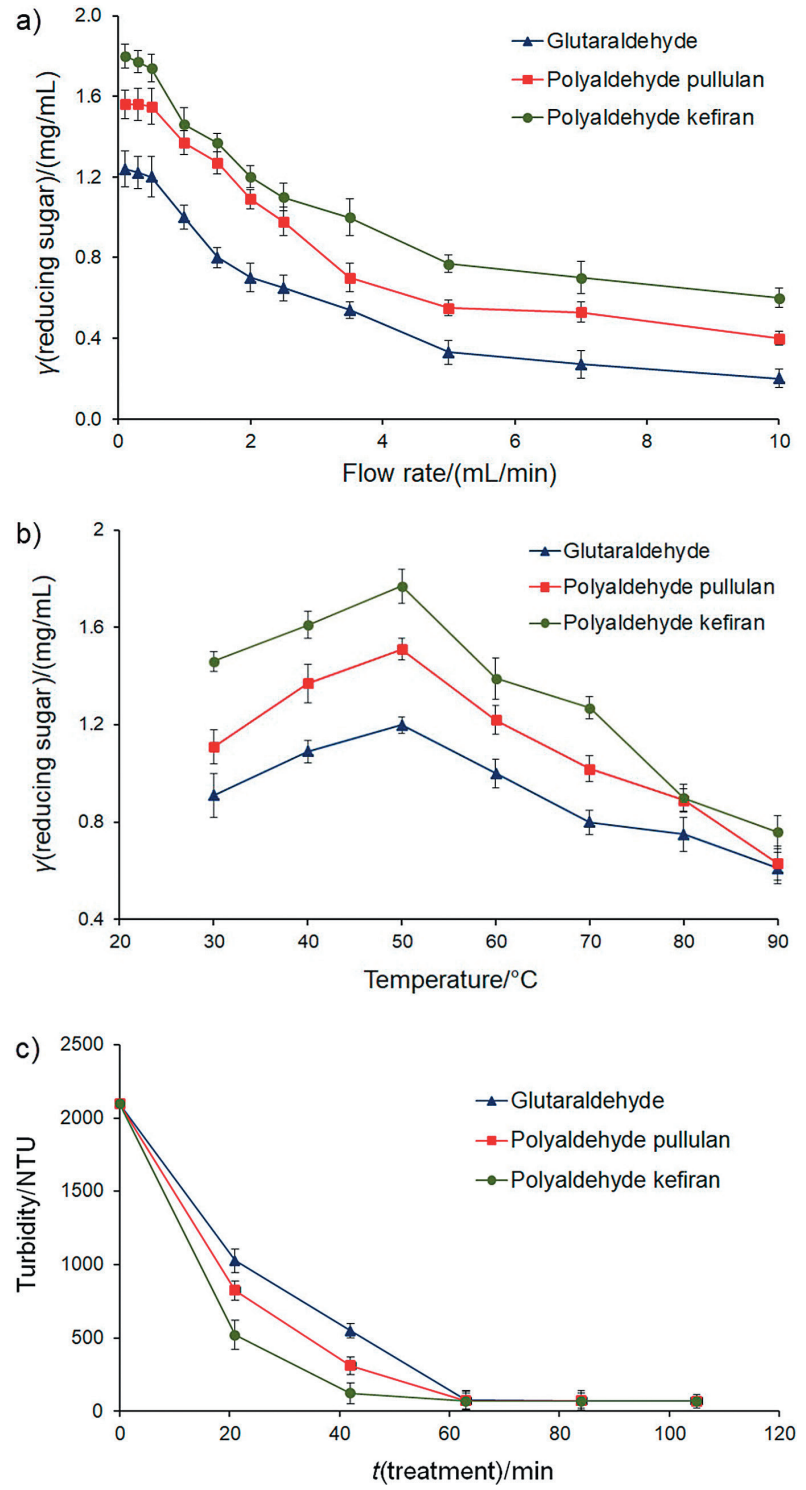

Fig. 2. The effect on the packed bed reactor performance of: a) flow rate at $50{ }^{\circ} \mathrm{C}, \mathrm{b}$ ) temperature at flow rate of $0.5 \mathrm{~mL} / \mathrm{min}$, and c) treatment time at $50^{\circ} \mathrm{C}$ and flow rate of $0.5 \mathrm{~mL} / \mathrm{min}$. Glutaraldehyde, polyaldehyde pullulan and polyaldehyde kefiran=the bioreactor packed with pectinase immobilised on glass beads by glutaraldehyde, polyaldehyde derivatives of pullulan and kefiran, respectively. Data are presented as mean value \pm S.D., $N=3$. NTU=nephelometric turbidity unit

the obtained results are shown in Fig. 3. As can be seen, the maximum volumetric productivity was obtained with pectinase immobilised by polyaldehyde derivative of kefiran in continuous operation, followed by the enzyme immobilised by polyaldehyde derivative of kefiran in batch operation. The higher volumetric productivity of pectinase immobilised by polyaldehyde derivative of kefiran than the other applied cross-linkers was due to the better capacity of this cross-linker for enzyme immobilisation, as mentioned before. Also, the higher volumetric productivity in continuous operation than the batch type was possibly due to better contact between 


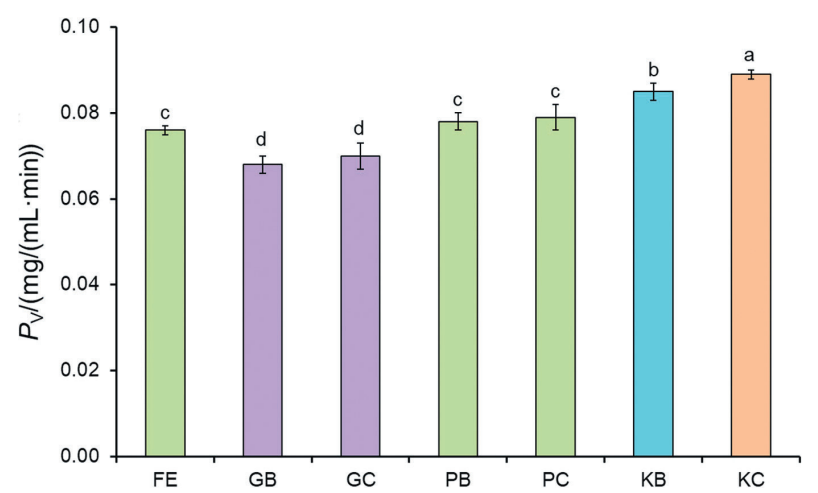

Fig. 3. Volumetric productivity of free and immobilised pectinase in the batch and continuous operations. $\mathrm{FE}=$ free pectinase, $\mathrm{GB}=$ pectinase immobilised by glutaraldehyde in the batch operation, $\mathrm{GC}=$ pectinase immobilised by glutaraldehyde in the continuous operation, $\mathrm{PB}=$ pectinase immobilised by polyaldehyde derivative of pullulan in the batch operation, $\mathrm{PC}=$ pectinase immobilised by polyaldehyde derivative of pullulan in the continuous operation, $\mathrm{KB}=$ pectinase immobilised by polyaldehyde derivative of kefiran in the batch operation, $\mathrm{KC}=$ pectinase immobilised by polyaldehyde derivative of kefiran in the continuous operation. Data are presented as mean value $\pm S . D ., N=3$. Different letters indicate significant differences $(p<0.05)$

the immobilised pectinase and the substrate in the continuous process. The volumetric productivity of pectinase immobilised by polyaldehyde derivative of pullulan was lower than of pectinase immobilised by polyaldehyde derivative of kefiran, but higher than of glutaraldehyde-immobilised enzyme, due to the amount of the immobilised enzyme. As mentioned earlier, the protein content in free pectinase and in glutaraldehyde-immobilised enzyme was equal and according to Fig. 3 , the volumetric productivity of free enzymes was higher than of glutaraldehyde-immobilised ones, which was possibly related to the decrease in enzyme activity due to immobilisation, as shown in previous studies $(20,24)$.

\section{Effect of clarification on barberry juice properties}

After clarification under optimum conditions (flow rate $0.5 \mathrm{~mL} / \mathrm{min}$, temperature $50^{\circ} \mathrm{C}$ and treatment time $63 \mathrm{~min}$ for continuous and the same temperature and treatment time for batch operation) using free pectinase and pectinase immobilised by different cross-linkers in the batch and continuous operations, the physicochemical, antioxidant and colour properties of the treated barberry juice were evaluated and the obtained results were compared with the untreated sample.

\section{Physicochemical and colour properties}

Table 1 shows the physicochemical properties of the untreated and clarified juice samples. The most important goal in the fruit juice clarification is to reduce the turbidity and increase clarity. The main cause of this turbidity is the pectin present in the fruit juice and therefore its hydrolysis is necessary (40). Table 1 indicates that after clarification, the turbidity of barberry juice samples significantly decreased from 2068.8 to 69.3 NTU and thereby the clarity increased from 28.38 to $73.63 \%$. Also, the obtained results in Table 1 indicate that the applied immobilisation method (the use of polyaldehyde derivatives of kefiran and pullulan as cross-linkers) for the clarification of barberry juice was much more efficient than the common method (the use of glutaraldehyde as cross-linker). Besides, the mentioned results were in accordance with the reported data for the clarification of different fruit juice samples by Bilal et al. (41) and the clarification of apple juice by Deng et al. (42).

Table 1 shows that the $\mathrm{pH}$ of barberry juice samples decreased after clarification, which was in line with the obtained data for the apple juice clarified by the pectinase immobilised in calcium alginate microspheres (42). Also, the TTA of the

Table 1. Physicochemical characterisation of barberry juice including turbidity, clarity, pH, total titratable acidity (TTA), total soluble solids (TSS), reducing sugar content, viscosity, pectin presence and total phenolic content

$\begin{array}{lccccccccc}\text { Parameter } & \text { RBJ } & \text { BFP } & \text { BGB } & \text { BGC } & \text { BPB } & \text { BPC } & \text { BKB } & \text { BKC } \\ \text { Turbidity/NTU } & (2068.8 \pm 0.0)^{\mathrm{a}} & (72.6 \pm 0.4)^{\mathrm{d}} & (75.1 \pm 0.8)^{\mathrm{b}} & (73.8 \pm 0.3)^{\mathrm{c}} & (73.0 \pm 0.4)^{\mathrm{d}} & (72.7 \pm 0.3)^{\mathrm{d}} & (71.7 \pm 0.4)^{\mathrm{e}} & (69.3 \pm 0.6)^{\mathrm{f}} \\ \text { Clarity/\% } & (28.4 \pm 0.2)^{\mathrm{h}} & (61.7 \pm 0.2)^{\mathrm{e}} & (54.1 \pm 0.1)^{\mathrm{g}} & (60.3 \pm 0.1)^{\mathrm{f}} & (63.0 \pm 0.1)^{\mathrm{d}} & (65.13 \pm 0.09)^{\mathrm{c}} & (68.2 \pm 0.1)^{\mathrm{b}} & (73.6 \pm 0.1)^{\mathrm{a}} \\ \mathrm{pH} & (3.21 \pm 0.02)^{\mathrm{a}} & (2.99 \pm 0.02)^{\mathrm{e}} & (3.18 \pm 0.01)^{\mathrm{b}} & (3.14 \pm 0.02)^{\mathrm{c}} & (3.09 \pm 0.02)^{\mathrm{d}} & (2.98 \pm 0.04)^{\mathrm{e}} & (2.77 \pm 0.01)^{\mathrm{f}} & (2.70 \pm 0.03)^{\mathrm{g}} \\ \mathrm{TTA} /(\mathrm{g} / 100 \mathrm{~mL}) & (0.75 \pm 0.03)^{\mathrm{g}} & (1.04 \pm 0.02)^{\mathrm{d}} & (0.91 \pm 0.03)^{\mathrm{f}} & (0.97 \pm 0.01)^{\mathrm{e}} & (1.13 \pm 0.01)^{\mathrm{c}} & (1.14 \pm 0.02)^{\mathrm{c}} & (1.21 \pm 0.02)^{\mathrm{b}} & (1.29 \pm 0.03)^{\mathrm{a}} \\ \mathrm{TSS} /{ }^{\circ} \text { Brix } & (30.5 \pm 0.0)^{\mathrm{a}} & (25.5 \pm 0.0)^{\mathrm{d}} & (29.0 \pm 0.0)^{\mathrm{b}} & (29.0 \pm 0.0)^{\mathrm{b}} & (26.0 \pm 0.0)^{\mathrm{c}} & (25.5 \pm 0.0)^{\mathrm{d}} & (21.5 \pm 0.0)^{\mathrm{e}} & (21.0 \pm 0.0)^{\mathrm{f}} \\ \begin{array}{l}\text { (reducing sugar)/ } \\ \text { (mg/mL) }\end{array} & (53.2 \pm 0.2)^{\mathrm{h}} & (63.4 \pm 0.2)^{\mathrm{e}} & (60.3 \pm 0.2)^{\mathrm{g}} & (62.8 \pm 0.1)^{\mathrm{f}} & (64.1 \pm 0.1)^{\mathrm{d}} & (66.2 \pm 0.1)^{\mathrm{c}} & (69.1 \pm 0.1)^{\mathrm{b}} & (69.57 \pm 0.09)^{\mathrm{a}} \\ \begin{array}{l}\eta /(\mathrm{mPa} \cdot \mathrm{s}) \\ \text { Pectin presence }\end{array} & (4.6 \pm 0.2)^{\mathrm{a}} & (4.07 \pm 0.04)^{\mathrm{b}} & (4.2 \pm 0.2)^{\mathrm{b}} & (4.2 \pm 0.1)^{\mathrm{b}} & (4.0 \pm 0.1)^{\mathrm{bc}} & (3.91 \pm 0.07)^{\mathrm{c}} & (3.6 \pm 0.1)^{\mathrm{d}} & (3.3 \pm 0.1)^{\mathrm{e}} \\ \gamma(\text { total phenolics)/ } & \text { Yes } & \text { No } & \text { No } & \text { No } & \text { No } & \text { No } & \text { No } & \text { No } \\ (\mathrm{mg} / \mathrm{mL}) & (20.3 \pm 0.1)^{\mathrm{a}} & (19.3 \pm 0.1)^{\mathrm{b}} & (19.6 \pm 0.2)^{\mathrm{b}} & (19.5 \pm 0.1)^{\mathrm{b}} & (19.4 \pm 0.1)^{\mathrm{b}} & (18.9 \pm 0.1)^{\mathrm{c}} & (18.8 \pm 0.2)^{\mathrm{c}} & (18.54 \pm 0.04)^{\mathrm{d}}\end{array}$

$\mathrm{RBJ}=$ raw barberry juice, $\mathrm{BFP}=$ barberry juice treated with free pectinase, $\mathrm{BGB}=$ barberry juice treated with pectinase immobilised by glutaraldehyde in batch operation, $B G C=$ barberry juice treated with pectinase immobilised by glutaraldehyde in continuous operation, $\mathrm{BPB}=$ barberry juice treated with pectinase immobilised by polyaldehyde derivative of pullulan in batch operation, $\mathrm{BPC}=$ barberry juice treated with pectinase immobilised by polyaldehyde derivative of pullulan in continuous operation, $B K B=b a r b e r r y$ juice treated with pectinase immobilised by polyaldehyde derivative of kefiran in batch operation, BKC=barberry juice treated with pectinase immobilised by polyaldehyde derivative of kefiran in continuous operation. $N T U=$ nephelometric turbidity unit. Data are presented as mean value $\pm S . D ., N=3$. Different letters in the same row indicate significant differences $(p<0.05)$ 
juice samples was significantly increased by clarification, which can be related to the liberation of organic acids, especially galacturonic acid, during pectin hydrolysis by pectinase (43).

The obtained results of TSS determination indicate that this parameter decreased after clarification, probably due to the deposition of the suspended solid compounds after pectin hydrolysis and the destruction of the network formed by it. Also, the findings show that clarification led to an increase in the reducing sugar concentration in the treated fruit juice, possibly due to the release of these sugars by pectin hydrolysis.

Pectin has a high water-holding capacity and creates a cohesive network structure. Therefore, pectin hydrolysis by free and/or immobilised pectinase can reduce water holding capacity, release the water into the fruit juice and thereby reduce the viscosity (11). As observable in Table 1, the viscosity of the fruit juice samples clarified by all treatments was significantly lower than the untreated sample. Other researchers also reported similar results $(25,44)$. The results of pectin determination show that no pectin was observed in the fruit juice samples after clarification by free or immobilised pectinase in the batch and continuous operations (Table 1), indicating that pectin was completely hydrolysed.

Three colour parameters including $L$ (lightness), a (green-red value) and $b$ (blue-yellow value) of the untreated barberry juice and the samples clarified by free and immobilised enzymes were evaluated and the obtained data are shown in Table 2. The lightness factor was increased by the enzymatic clarification. This result was expected because a decrease in turbidity and increase in clarity led to the increase in $L$ value, which was in agreement with the reported data by de Oliveira et al. (11) and Sin et al. (44) for clarified apple and sapodilla juice, respectively. Also, the obtained results indicated that clarification led to a decrease in the green-red value and an increase in the blue-yellow value (Table 2). The decrease in red colour after pectin hydrolysis can be due to the deposition of some antioxidant compounds that are red in the acidic fruit juice.

Table 1 shows that TPC was significantly reduced by the clarification, which was in agreement with the reported data by Landbo et al. (43) and Diano et al. (25) for the clarified black currant and apple juice, respectively. This was attributed to the deposition of phenolic compounds after pectin hydrolysis and also to the change of the phenolic compound profile during secondary enzymatic activity (11).

From the results in Table 1, it is clear that the bioreactor packed with pectinase immobilised by polyaldehyde derivative of kefiran had the greatest effect on the measured parameters, which could be attributed to the more effective enzyme immobilisation by the mentioned cross-linker. Besides, the continuous operation performed better than the batch type, probably due to better contact between the immobilised pectinase and the substrate in the continuous process.

\section{Antioxidant properties}

In this experiment, DPPH and ABTS radical scavenging activities of the untreated and treated barberry juice samples were determined to evaluate their antioxidant properties, and the obtained results are shown in Fig. 4. As can be seen,

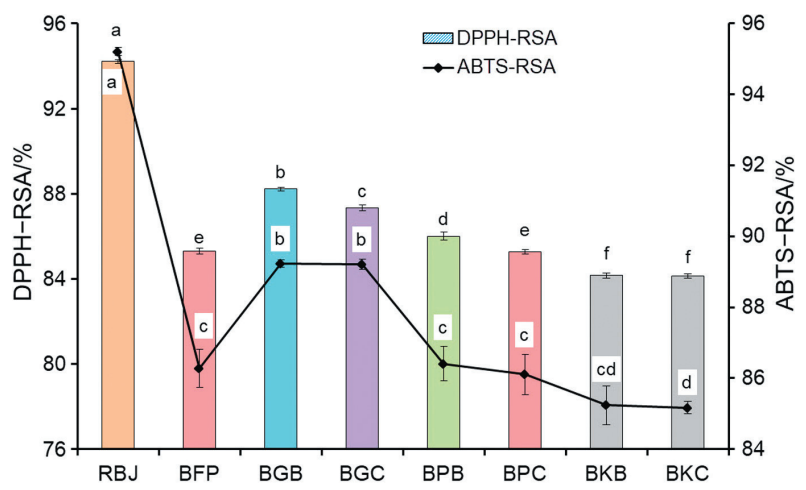

Fig. 4. DPPH radical scavenging activity (DPPH-RSA) and ABTS radical scavenging activity (ABTS-RSA) of the untreated and treated barberry juice. $\mathrm{RBJ}=$ raw barberry juice, $\mathrm{BFP}=$ barberry juice treated with free pectinase, $B G B=$ barberry juice treated with pectinase immobilised by glutaraldehyde in batch operation, $B G C=$ barberry juice treated with pectinase immobilised by glutaraldehyde in continuous operation, $\mathrm{BPB}=$ barberry juice treated with pectinase immobilised by polyaldehyde derivative of pullulan in batch operation, BPC=barberry juice treated with pectinase immobilised by polyaldehyde derivative of pullulan in continuous operation, BKB=barberry juice treated with pectinase immobilised by polyaldehyde derivative of kefiran in batch operation, BKC=barberry juice treated with pectinase immobilised by polyaldehyde derivative of kefiran in continuous operation. Data are presented as mean value \pm S.D., $N=3$. Different letters indicate significant differences $(p<0.05)$

Table 2. The colour parameters of the untreated and treated barberry juice

\begin{tabular}{lcccccccc} 
Parameter & RBJ & BFP & BGB & BGC & BPB & BPC & BKB & BKC \\
\hline$L$ & $(10.21 \pm 0.03)^{\mathrm{e}}$ & $(18.1 \pm 0.2)^{\mathrm{c}}$ & $(17.1 \pm 0.2)^{\mathrm{d}}$ & $(17.2 \pm 0.1)^{\mathrm{d}}$ & $(17.5 \pm 0.2)^{\mathrm{d}}$ & $(18.32 \pm 0.09)^{\mathrm{c}}$ & $(20.4 \pm 0.2)^{\mathrm{b}}$ & $(21.1 \pm 0.1)^{\mathrm{a}}$ \\
$a$ & $(22.2 \pm 0.1)^{\mathrm{a}}$ & $(19.2 \pm 0.1)^{\mathrm{c}}$ & $(20.3 \pm 0.1)^{\mathrm{b}}$ & $(20.2 \pm 0.1)^{\mathrm{b}}$ & $(18.4 \pm 0.1)^{\mathrm{d}}$ & $(18.3 \pm 0.2)^{\mathrm{d}}$ & $(17.2 \pm 0.1)^{\mathrm{e}}$ & $(17.14 \pm 0.07)^{\mathrm{e}}$ \\
$b$ & $(4.1 \pm 0.1)^{\mathrm{c}}$ & $(5.0 \pm 0.2)^{\mathrm{b}}$ & $(5.0 \pm 0.2)^{\mathrm{b}}$ & $(5.1 \pm 0.1)^{\mathrm{b}}$ & $(5.1 \pm 0.1)^{\mathrm{b}}$ & $(5.2 \pm 0.1)^{\mathrm{b}}$ & $(5.51 \pm 0.08)^{\mathrm{a}}$ & $(5.7 \pm 0.1)^{\mathrm{a}}$
\end{tabular}

$\mathrm{RBJ}=$ raw barberry juice, $\mathrm{BFP}=$ barberry juice treated with free pectinase, $\mathrm{BGB}=$ barberry juice treated with pectinase immobilised by glutaraldehyde in batch operation, $B G C=$ barberry juice treated with pectinase immobilised by glutaraldehyde in continuous operation, $\mathrm{BPB}=$ barberry juice treated with pectinase immobilised by polyaldehyde derivative of pullulan in batch operation, $\mathrm{BPC}=$ barberry juice treated with pectinase immobilised by polyaldehyde derivative of pullulan in continuous operation, $B K B=$ barberry juice treated with pectinase immobilised by polyaldehyde derivative of kefiran in batch operation, $\mathrm{BKC}=$ barberry juice treated with pectinase immobilised by polyaldehyde derivative of kefiran in continuous operation. Data are presented as mean value $\pm S$.D., $N=3$. Different letters in the same row indicate significant differences $(p<0.05)$ 
both parameters were significantly reduced after the clarification. These observations were probably related to the decrease in TPC, which has a direct effect on antioxidant properties $(11,45)$ and to the deposition of some other antioxidant compounds after pectin hydrolysis. Fig. 4 shows that pectinase immobilised by polyaldehyde derivative of kefiran led to the greatest reduction in antioxidant properties as a result of better ability of the cross-linker to immobilise the enzymes.

\section{CONCLUSIONS}

In this study, different cross-linkers (glutaraldehyde and polyaldehyde derivatives of pullulan and kefiran) were applied to immobilise pectinase on the functionalised glass beads and the barberry juice was clarified in batch and continuous operations using immobilised enzyme. The results show that the best packed bed reactor performance was obtained at a flow rate $0.5 \mathrm{~mL} / \mathrm{min}$, temperature $50{ }^{\circ} \mathrm{C}$ and treatment time $63 \mathrm{~min}$. Also, the physicochemical, colour and antioxidant properties of the barberry juice significantly changed after clarification. Under the optimum conditions, the turbidity of the fruit juice samples clarified by pectinase immobilised by polyaldehyde derivatives of pullulan and kefiran was significantly lower than of the samples clarified by glutaraldehyde-immobilised pectinase, which was related to the better ability of these new cross-linkers to immobilise the pectinase.

\section{FUNDING}

This study was financially supported by the Iran National Science Foundation (INSF), Iran (grant no. 97011331), as part of the project 'Continuous clarification of fruit juice in packed bed bioreactor by covalent immobilization of pectinase enzyme on the glass beads with aldehyde polysaccharides'.

\section{CONFLICT OF INTEREST}

The authors declare that they have no conflict of interest.

\section{AUTHORS' CONTRIBUTION}

S.S. Hosseini contributed to data collection, data analysis and interpretation, drafting the article and offering critical revision. F. Khodaiyan participated in the design of the work, performing the analysis, providing critical review and supervision. S.M. Mousavi assisted in the design of the work, performing the analysis, final approval and supervision. S.Z. Azimi contributed to planning data collection and performing the analysis.

\section{ORCID ID}

S.S. Hosseini (1) https://orcid.org/0000-0002-0822-5541

F. Khodaiyan (1) https://orcid.org/0000-0003-2384-4145

S.M. Mousavi (1) https://orcid.org/0000-0001-5194-0260

S.Z. Azimi 『 https://orcid.org/0000-0002-2840-0327

\section{REFERENCES}

1. Alizadeh HR, Mortezapour H, Akhavan HR, Balvardi M. Performance of a liquid desiccant-assisted solar juice concentration system for barberry juice. Sol Energy. 2019;184:1-10. https://doi.org/10.1016/j.solener.2019.03.085

2. Sarraf M, Beig Babaei A, Naji-Tabasi S. Investigating functional properties of barberry species: An overview. J Sci Food Agr. 2019;99(12):5255-69.

https://doi.org/10.1002/jsfa.9804

3. Kazemi M, Khodaiyan F, Labbafi M, Hosseini SS. Ultrasonic and heating extraction of pistachio by-product pectin: Physicochemical, structural characterization and functional measurement. J Food Meas Charact. 2020;14:679-93. https://doi.org/10.1007/s11694-019-00315-0

4. Asgari K, Labbafi M, Khodaiyan F, Kazemi M, Hosseini SS. High-methylated pectin from walnut processing wastes as a potential resource: Ultrasound assisted extraction and physicochemical, structural and functional analysis. Int J Biol Macromol. 2020;152:1274-82.

https://doi.org/10.1016/j.ijbiomac.2019.10.224

5. Shahrestani H, Taheri-Kafrani A, Soozanipour A, Tavakoli O. Enzymatic clarification of fruit juices using xylanase immobilized on 1,3,5-triazine-functionalized silica-encapsulated magnetic nanoparticles. Biochem Eng J. 2016;109:51-8. https://doi.org/10.1016/j.bej.2015.12.013

6. Goh WJ, Makam VS, Hu J, Kang L, Zheng M, Yoong SL, et al. Iron oxide filled magnetic carbon nanotube-enzyme conjugates for recycling of amyloglucosidase: Toward useful applications in biofuel production process. Langmuir. 2012; 28(49):16864-73.

https://doi.org/10.1021/la303046m

7. Dal Magro L, de Moura KS, Backes BE, de Menezes EW, Benvenutti EV, Nicolodi S, et al. Immobilization of pectinase on chitosan-magnetic particles: Influence of particle preparation protocol on enzyme properties for fruit juice clarification. Biotechnol Rep. 2019;24:e00373. https://doi.org/10.1016/j.btre.2019.e00373

8. Cerreti M, Liburdi K, Benucci I, Esti M. The effect of pectinase and protease treatment on turbidity and on haze active molecules in pomegranate juice. LWT - Food Sci Technol. 2016;73:326-33.

https://doi.org/10.1016/j.lwt.2016.06.030

9. Sojitra UV, Nadar SS, Rathod VK. A magnetic tri-enzyme nanobiocatalyst for fruit juice clarification. Food Chem. 2016;213:296-305. https://doi.org/10.1016/j.foodchem.2016.06.074

10. Azar RISL, da Luz Morales M, Maitan-Alfenas GP, Falkoski $\mathrm{DL}$, Alfenas RF, Guimaraes VM. Apple juice clarification by a purified polygalacturonase from Calonectria pteridis. Food Bioprod Process. 2020;119:238-45.

https://doi.org/10.1016/j.fbp.2019.11.013 
11. de Oliveira RL, Dias JL, da Silva OS, Porto TS. Immobilization of pectinase from Aspergillus aculeatus in alginate beads and clarification of apple and umbu juices in a packed bed reactor. Food Bioprod Process. 2018;109:9-18.

https://doi.org/10.1016/j.fbp.2018.02.005

12. Rong J, Zhou Z, Wang Y, Han J, Li C, Zhang W, Ni L. Immobilization of horseradish peroxidase on multi-armed magnetic graphene oxide composite: improvement of loading amount and catalytic activity. Food Technol Biotechnol. 2019;57(2):260-71.

https://doi.org/10.17113/ftb.57.02.19.5832

13. Cui J, Jia S. Organic-inorganic hybrid nanoflowers: A novel host platform for immobilizing biomolecules. Coordin Chem Rev. 2017;352:249-63.

https://doi.org/10.1016/j.ccr.2017.09.008

14. Cui JD, Jia SR. Optimization protocols and improved strategies of cross-linked enzyme aggregates technology: Current development and future challenges. Crit Rev Biotechnol. 2015;35(1):15-28.

https://doi.org/10.3109/07388551.2013.795516

15. Bilal M, Cui J, Iqbal HM. Tailoring enzyme microenvironment: State-of-the-art strategy to fulfill the quest for efficient bio-catalysis. Int J Biol Macromol. 2019;130:186-96. https://doi.org/10.1016/j.ijbiomac.2019.02.141

16. Abdel Wahab WA, Karam EA, Hassan ME, Kansoh AL, Esawy MA, Awad GEA. Optimization of pectinase immobilization on grafted alginate-agar gel beads by $2^{4}$ full factorial CCD and thermodynamic profiling for evaluating of operational covalent immobilization. Int J Biol Macromol. 2018;113: 159-70.

https://doi.org/10.1016/j.ijbiomac.2018.02.086

17. Hassan SS, Williams GA, Jaiswal AK. Computational modelling approach for the optimization of apple juice clarification using immobilized pectinase and xylanase enzymes. Curr Res Food Sci. 2020;3:243-55.

https://doi.org/10.1016/j.crfs.2020.09.003

18. Benucci I, Mazzocchi C, Lombardelli C, Cacciotti I, Esti M. Multi-enzymatic systems immobilized on chitosan beads for pomegranate juice treatment in fluidized bed reactor: Effect on haze-active molecules and chromatic properties. Food Bioprocess Technol. 2019;12:1559-72.

https://doi.org/10.1007/s11947-019-02315-w

19. Gomez JL, Bodalo A, Gomez E, Bastida J, Hidalgo AM, Gomez M. Immobilization of peroxidases on glass beads: an improved alternative for phenol removal. Enzyme Microbial Technol. 2006;39(5):1016-22.

https://doi.org/10.1016/j.enzmictec.2006.02.008

20. Lei Z, Jiang Q. Synthesis and properties of immobilized pectinase onto the macroporous polyacrylamide microspheres. J Agric Food Chem. 2011;59(6):2592-9.

https://doi.org/10.1021/jf103719t

21. Dahiya P, Chand S, Dilbaghi N. Immobilization of organic solvent-tolerant lipase from Pseudomonas mendocina M-37 with potential synthetic activities. Food Technol Biotechnol. 2014;52(3):368-75.

22. Cui J, Ren S, Sun B, Jia S. Optimization protocols and improved strategies for metal-organic frameworks for immobilizing enzymes: Current development and future challenges. Coord Chem Rev. 2018;370:22-41.

https://doi.org/10.1016/j.ccr.2018.05.004

23. Bodalo A, Gomez E, Gomez JL, Bastida J, Maximo MF, Diaz F. A comparison of different methods of $\beta$-galactosidase immobilization. Process Biochem. 1991;26(6):349-53.

https://doi.org/10.1016/0032-9592(91)85025-J

24. Hosseini SS, Khodaiyan F, Mousavi SME, Azimi SZ, Gharaghani M. Immobilization of pectinase on the glass bead using polyaldehyde kefiran as a new safe cross-linker and its effect on the activity and kinetic parameters. Food Chem. 2020;309:125777.

https://doi.org/10.1016/j.foodchem.2019.125777

25. Diano N, Grimaldi T, Bianco M, Rossi S, Gabrovska K, Yordanova G, et al. Apple juice clarification by immobilized pectolytic enzymes in packed or fluidized bed reactors. J Agric Food Chem. 2008;56(23):11471-7.

https://doi.org/10.1021/jf8019437

26. Dal Magro L, Pessoa JP, Klein MP, Fernandez-Lafuente R, Rodrigues RC. Enzymatic clarification of orange juice in continuous bed reactors: Fluidized-bed versus packed-bed reactor. Catal Today. 2021;362:184-91.

https://doi.org/10.1016/j.cattod.2020.02.003

27. Benucci I, Lombardelli C, Liburdi K, Acciaro G, Zappino M, Esti M. Immobilised native plant cysteine proteases: packed-bed reactor for white wine protein stabilisation. J Food Sci Technol. 2016;53(2):1130-9.

https://doi.org/10.1007/s13197-015-2125-4

28. Hosseini SS, Khodaiyan F, Mousavi SM, Kennedy JF, Azimi SZ. A health-friendly strategy for covalent-bonded immobilization of pectinase on the functionalized glass beads. Food Bioprocess Technol. 2021;14:177-86.

https://doi.org/10.1007/s11947-020-02524-8

29. Guo J, Ge L, Li X, Mu C, Li D. Periodate oxidation of xanthan gum and its crosslinking effects on gelatin-based edible films. Food Hydrocolloid. 2014;39:243-50.

https://doi.org/10.1016/j.foodhyd.2014.01.026

30. Kholiya F, Chaudhary JP, Vadodariya N, Meena R. Synthesis of bio-based aldehyde from seaweed polysaccharide and its interaction with bovine serum albumin. Carbohydr Polym. 2016;150:278-85.

https://doi.org/10.1016/j.carbpol.2016.05.022

31. Lowry OH, Rosebrough NJ, Farr AL, Randall RJ. Protein measurement with the Folin phenol reagent. J Biol Chem. 1951;193:265-75.

32. Miller GL. Use of dinitrosalicylic acid reagent for determination of reducing sugar. Anal Chem. 1959;31(3):426-8.

https://doi.org/10.1021/ac60147a030 
33. Singh RS, Saini GK, Kennedy JF. Continuous hydrolysis of pullulan using covalently immobilized pullulanase in a packed bed reactor. Carbohydr Polym. 2011;83(2):672-5. https://doi.org/10.1016/j.carbpol.2010.08.037

34. Kazemi M, Khodaiyan F, Hosseini SS, Najari Z. An integrated valorization of industrial waste of eggplant: Simultaneous recovery of pectin, phenolics and sequential production of pullulan. Waste Managem. 2019;100:101-11.

https://doi.org/10.1016/j.wasman.2019.09.013

35. Feizy J, Jahani M, Ahmadi S. Antioxidant activity and mineral content of watermelon peel. J Food Bioprocess Eng. 2020;3(1):35-40.

https://doi.org/10.22059/JFABE.2020.75811

36. Karimi S, Sharifzadeh S, Abbasi H. Sequential ultrasound-microwave assisted extraction as a green method to extract essential oil from Zataria multiflora. J Food Bioprocess Eng. 2020;3(2):101-9.

https://doi.org/10.22059/JFABE.2020.308833.1064

37. IBM SPSS, v. 20, IBM Corp., Armonk, NY, USA; 2020. Available from: https://www.ibm.com/products/spss-statistics.

38. Ansari SA, Husain Q. Lactose hydrolysis by $\beta$ galactosidase immobilized on concanavalin A-cellulose in batch and continuous mode. J Mol Catal B Enzym. 2010;63:68-74. https://doi.org/10.1016/j.molcatb.2009.12.010

39. Dal Magro L, Silveira VCC, de Menezes EW, Benvenutti EV, Nicolodi S, Hertz PF, et al. Magnetic biocatalysts of pectinase and cellulase: Synthesis and characterization of two preparations for application in grape juice clarification. Int
J Biol Macromol. 2018;115:35-44.

https://doi.org/10.1016/j.ijbiomac.2018.04.028

40. Sharma HP, Patel H, Sharma S. Enzymatic extraction and clarification of juice from various fruits - A review. Trends Post Harvest Technol. 2014;2(1):1-14.

41. Bilal M, Asgher M, Iqbal HMN, Hu H, Zhang X. Delignification and fruit juice clarification properties of alginate-chitosan-immobilized ligninolytic cocktail. LWT - Food Sci Technol. 2017;80:348-54.

https://doi.org/10.1016/j.lwt.2017.02.040

42. Deng Z, Wang F, Zhou B, Li J, Li B, Liang H. Immobilization of pectinases into calcium alginate microspheres for fruit juice application. Food Hydrocolloid. 2019;89:691-9. https://doi.org/10.1016/j.foodhyd.2018.11.031

43. Landbo AKR, Pinelo M, Vikbjerg AF, Let MB, Meyer AS. Protease-assisted clarification of black currant juice: synergy with other clarifying agents and effects on the phenol content. J Agric Food Chem. 2006;54(18):6554-63. https://doi.org/10.1021/jf060008d

44. Sin HN, Yusof S, Hamid NSA, Rahman RA. Optimization of enzymatic clarification of sapodilla juice using response surface methodology. J Food Eng. 2006;73(4):313-9. https://doi.org/10.1016/j.jfoodeng.2005.01.031

45. Su MS, Silva JL. Antioxidant activity, anthocyanins, and phenolics of rabbiteye blueberry (Vaccinium ashei) by-products as affected by fermentation. Food Chem. 2006;97(3):447-51.

https://doi.org/10.1016/j.foodchem.2005.05.023 